\title{
AN INTEGRATED STRATEGY FOR THE CONSERVATION AND SUSTAINABLE USE OF NATIVE VANILLA SPECIES IN COLOMBIA
}

\author{
Nicola S. Flanagan ${ }^{1,2} \&$ Ana Teresa Mosquera-Espinosa ${ }^{1}$ \\ ${ }^{1}$ Departamento de Ciencias Naturales y Matemáticas, Pontificia Universidad Javeriana-Cali, Colombia \\ ${ }^{2}$ Author for correspondence: nsflanagan@javerianacali.edu.co
}

\begin{abstract}
The natural vanilla essence is obtained principally from the fruits of the species Vanilla planifolia, a member of the Vanilla aromatic clade, and native to the neo-tropics. Colombia is an important center of diversity for the genus with 22 Vanilla species reported, of which 18 belong to the aromatic clade. Colombian native Vanilla species comprise important genetic resources for the vanilla crop. Although there is no tradition of cultivation of vanilla in the country, these species have potential for establishment in sustainable agroforestry systems. Nonetheless, Vanilla, like many orchid species, is subject to both intrinsic and extrinsic conservation threats. This article outlines an integrated strategy for conservation, incorporating in situ, ex situ and circa situm measures to ensure the conservation of Vanilla species in Colombia, and to promote their sustainable use in community-based cultivation programs. This proposed strategy is also relevant for conservation managers in other countries with native Vanilla species.
\end{abstract}

Key words: Vanilla crop wild relatives, mycorrhizal fungi, in situ, ex situ, circa situm conservation, Vanilla Endophyte Collection

Introduction. Vanilla is one of the most economically important crops for low-altitude humid tropical regions, and is now cultivated globally. The natural fragrance of vanilla is a widely-used ingredient in both the food and cosmetic industries, and is obtained from the cured fruits of orchids in the genus Vanilla (Orchidaceae); principally the species Vanilla planifolia G. Jacks., and hybrid derivatives, native to the neo-tropics (SotoArenas 2003, 2006).

The vanilla crop is almost exclusively vegetativelypropagated, leading to low levels of genetic variation (Bory et al. 2008), and making the crop vulnerable to pathogen infestation. The fungal pathogen, Fusarium oxysporum f. sp. radicis-vanillae (Koyyappurath et al. 2015a), that causes root and stem rot is one of several with a severe impact on vanilla production systems (Hernandez-Hernandez 2011). Crop improvement programs to combat this susceptibility, as well as to incorporate further desirable traits in the development of new commercial vanilla cultivars are limited by a lack of germplasm from both the primary and the secondary gene pool (Roux-Cuvelier \& Grisoni 2010). Despite the economic importance of this crop, it has received relatively little investigation, in particular with respect to the taxonomy, ecology and physiology of wild species in the genus.

Colombia is located at the center of the neotropical distribution for the aromatic Vanilla species, and recent studies indicate that a high diversity of Vanilla species is found in the country. This article aims to outline the diversity of Vanilla in the country, the apparent conservation threats, and the actions needed to develop an integrated strategy for the conservation and sustainable use of these valuable genetic resources in the country. Many of the actions we suggest will also be relevant for the conservation management of this valuable genus in other countries.

Vanilla diversity in Colombia. Colombia is the most biodiverse country for the Orchidaceae, with close to 4,300 species reported, including for the genus Vanilla (Ministerio de Ambiente y Desarrollo Sostenible [MADS] y Universidad Nacional de Colombia [UNAL] 2015). This genus in the basal subfamily Vanilloideae comprises monopodial, hemi-epiphytic to epiphytic climbing vines with branching stems. The genus has a pan-tropical distribution, and consists of roughly 110 species (Soto-Arenas \& Cribb 2010; and 
see Koch et al. 2013, Molineros-Hurtado et al. 2014, Pansarin et al. 2012, 2016). Within the neotropical region approximately 53 species are recognized, belonging to three distinct phylogenetic lineages: the basal membranaceous clade (Vanilla subgen. Vanilla sect. Membranacea Porteres) with 15 species; five Caribbean species that are phylogenetically related to African species; and finally the so-called aromatic clade (Vanilla subgen. Xanata sect. Xanata) with 33 species (Soto-Arenas \& Cribb 2010). The cultivated species $V$. planifolia, as well as other species with aromatic fruits, fall within this clade.

The study of taxonomy and distributions of Vanilla has been hampered due to the rarity of plants in natural habitat, their low flowering frequency and ephemeral flowers (lasting generally no more than 24 hours). Based on a review of literature and specimens deposited in the major international herbaria, SotoArenas \& Cribb (2010) registered eleven species for Colombia, ten of which fall in the aromatic clade. Herbaria in Colombia were, however, not consulted. Recent work in the field in Colombia has identified natural populations of twelve species, including four new reports for the country: $V$. bicolor, $V$. cribbiana, $V$. helleri, and $V$. phaeantha, and a confirmation of wild populations of $V$. planifolia (MolinerosHurtado 2012, Molineros-Hurtado et al., unpubl. data). Additionally a new species, $V$. rivasii has been described, named after the campesino who found the plant (Molineros-Hurtado et al. 2014). OrtizValdivieso (2015) listed two further species for the country, Vanilla palmarum and Vanilla penicillata both from the Amazon region. All these additional reports constitute species in the aromatic clade. The Colombian MADS \& UNAL (2015) report three additional species belonging to the Membranaceous clade: $V$. guianensis, $V$. inodora and $V$. mexicana, although these reports lack associated reference specimens, and may need botanical verification. Table 1 lists the reported species for Colombia, with sources. Figure 1 illustrates a number of Colombian native Vanilla species in natural habitat.

These reports bring the total number of species for Colombia to 22, of which 18 fall within the aromatic clade. Three of these aromatic species, Vanilla columbiana, V. espondae and V. rivasii are endemic to the country. Thus, Colombia represents an important center of diversity for this genus, and in particular for the aromatic clade. The Chocó Biogeographic region on the Pacific coast of Colombia is notably diverse, with eight aromatic species. For Central America and Mexico 15 Vanilla species are reported (SotoArenas \& Dressler, 2010). Soto-Arenas and Cribb (2010) recognize 26 species in Brazil, where further species have been described recently (Pansarin et al. 2012, Pansarin \& Miranda 2016), including Vanilla labellopapillata, affiliated to $V$. insignis and $V$. odorata (Koch et al. 2013).

The natural populations of aromatic Vanilla species in Colombia comprise important genetic resources for vanilla crop improvement, including both wild, locally adapted populations of $V$. planifolia, as well as other aromatic species. These crop wild relatives represent the secondary gene pool of cultivated vanilla, and some have already proved of value in cultivar development. For example, the cultivated $V . x$. tahitensis, grown exclusively in Tahiti, possesses distinct, valued organoleptic properties, and has been determined to be of hybrid origin between the two parental species $V$. planifolia and $V$. odorata (Lubinsky et al. 2008). Vanilla pompona has been used to develop hybrid cultivars with V. planifolia in Central America with an increased resistance to Fusarium infection (Belanger \& Havkin-Frenkel 2011).

In addition to their use in crop breeding programs for Vanilla planifolia, the direct cultivation of these native aromatic Vanilla species provides a promising opportunity for sustainable use of biological diversity, offering new products in a diversified fragrance and aroma market. Considerable differences exist in the relative compositions of volatiles both between species (Ranadive 2011), and between $V$. planifolia cultivars from different regions (Salazar-Rojas et al. 2011), and, as seen with $V x$. tahitensis, these differences may be of commercial interest.

In addition to consideration of plant diversity, the biological resources represented by the microbial diversity associated with wild Vanilla species must also be included in a comprehensive conservation program. Beneficial symbionts with positive functional roles in the natural environment may be of significant value in developing eco-efficient agricultural practices for the crop, and enhancing strategies for population reintroductions. 
TABLE 1. Register of presence of Vanilla species in Colombia. Historical distributions are based on herbarium records.

\begin{tabular}{|c|c|c|}
\hline Vanilla species & $\begin{array}{l}\text { Current known or Historical } \\
\text { Distribution in Colombia }\end{array}$ & Citation for presence in Colombia \\
\hline Vanilla bicolor Lindl. & Chocó & $\begin{array}{l}\text { Molineros-Hurtado, 2012; Molineros et al., } \\
\text { unpubl. data }\end{array}$ \\
\hline Vanilla calyculata Schltr. & Andean-Valle del Cauca & $\begin{array}{l}\text { Molineros-Hurtado, 2012; Molineros et al., } \\
\text { unpubl. data }\end{array}$ \\
\hline Vanilla columbiana Rolfe & Andean-Valle del Magdalena (historical) & Soto Arenas, 2010 \\
\hline Vanilla cribbiana Soto Arenas & Chocó & $\begin{array}{l}\text { Molineros-Hurtado 2012; Molineros et al., } \\
\text { unpubl. data }\end{array}$ \\
\hline Vanilla dressleri Soto Arenas & Chocó & $\begin{array}{l}\text { Molineros-Hurtado, 2012; Molineros et al., } \\
\text { unpubl. data }\end{array}$ \\
\hline Vanilla espondae Soto Arenas & Andean-Valle del Magdalena (historical) & Soto Arenas, 2010 \\
\hline Vanilla helleri Hawkes & Chocó & Molineros-Hurtado et al., unpubl. data \\
\hline Vanilla hostmanii Rolfe & Amazonia & Molineros-Hurtado et al., unpubl. data \\
\hline Vanilla guianensis Splitg. & Not registered & MADS \& UNAL, 2015 \\
\hline Vanilla inodora Schiede & Not registered & MADS \& UNAL, 2015 \\
\hline $\begin{array}{l}\text { Vanilla methonica Rchb.f \& } \\
\text { Warsz. }\end{array}$ & Amazonia (historical) & Soto Arenas, 2010 \\
\hline Vanilla mexicana Mill. & Not registered & MADS \& UNAL, 2015 \\
\hline Vanilla odorata C. Presl & Chocó; Andean & $\begin{array}{l}\text { Molineros-Hurtado, 2012; Molineros et al., } \\
\text { unpubl. data }\end{array}$ \\
\hline Vanilla palmarum Lindl & Amazonia (historical) & Ortiz-Valdivieso, 2015 \\
\hline $\begin{array}{l}\text { Vanilla penicillata Garay \& } \\
\text { Dunst }\end{array}$ & Llanos (historical) & Ortiz-Valdivieso, 2015 \\
\hline Vanilla phaeantha Rchb. & Llanos; Carribean & Molineros et al., unpubl. data \\
\hline Vanilla planifolia Andrews & Chocó & $\begin{array}{l}\text { Molineros-Hurtado 2012; Molineros et al., } \\
\text { unpubl. data }\end{array}$ \\
\hline Vanilla pompona Schiede & Andean-Valle del Cauca & Molineros et al., unpubl. data \\
\hline Vanilla riberoi Hoehne & Amazonia (historical) & Soto Arenas, 2010 \\
\hline $\begin{array}{l}\text { Vanilla rivasii Molineros-Hurtado } \\
\text { et al }\end{array}$ & Chocó & $\begin{array}{l}\text { Molineros-Hurtado, 2012; Molineros et al., } \\
\text { unpubl. data }\end{array}$ \\
\hline Vanilla sprucei Rolfe & Amazonia (historical) & Soto Arenas, 2010 \\
\hline Vanilla trigonocarpa Hoehne & Chocó & $\begin{array}{l}\text { Molineros-Hurtado 2012; Molineros et al., } \\
\text { unpubl. data }\end{array}$ \\
\hline
\end{tabular}

Threats to Vanilla conservation. The exceptional diversity of Vanilla in Colombia is subject to severe conservation threats, both due to intrinsic biological traits of these species, and to extrinsic anthropogenic activities.

Vanilla species, in common with many orchid species, are rare in natural habitats, and populations discovered in Colombia often comprise only a few, or a single individual. Flowering is rare, and natural pollination events are low (Molineros-Hurtado, 2012). Vanilla, like all orchids, requires an association with mycorrhizal fungi for seed germination (Porras-Alfaro \& Bayman 2007). Only one or two clear germinated propagules have been seen during field work, and natural reproduction of these species most likely includes considerable vegetative propagation, due to natural vine division (Flanagan \& Mosquera-Espinosa, unpub. data 2009-2015), leading to low genetic diversity in 


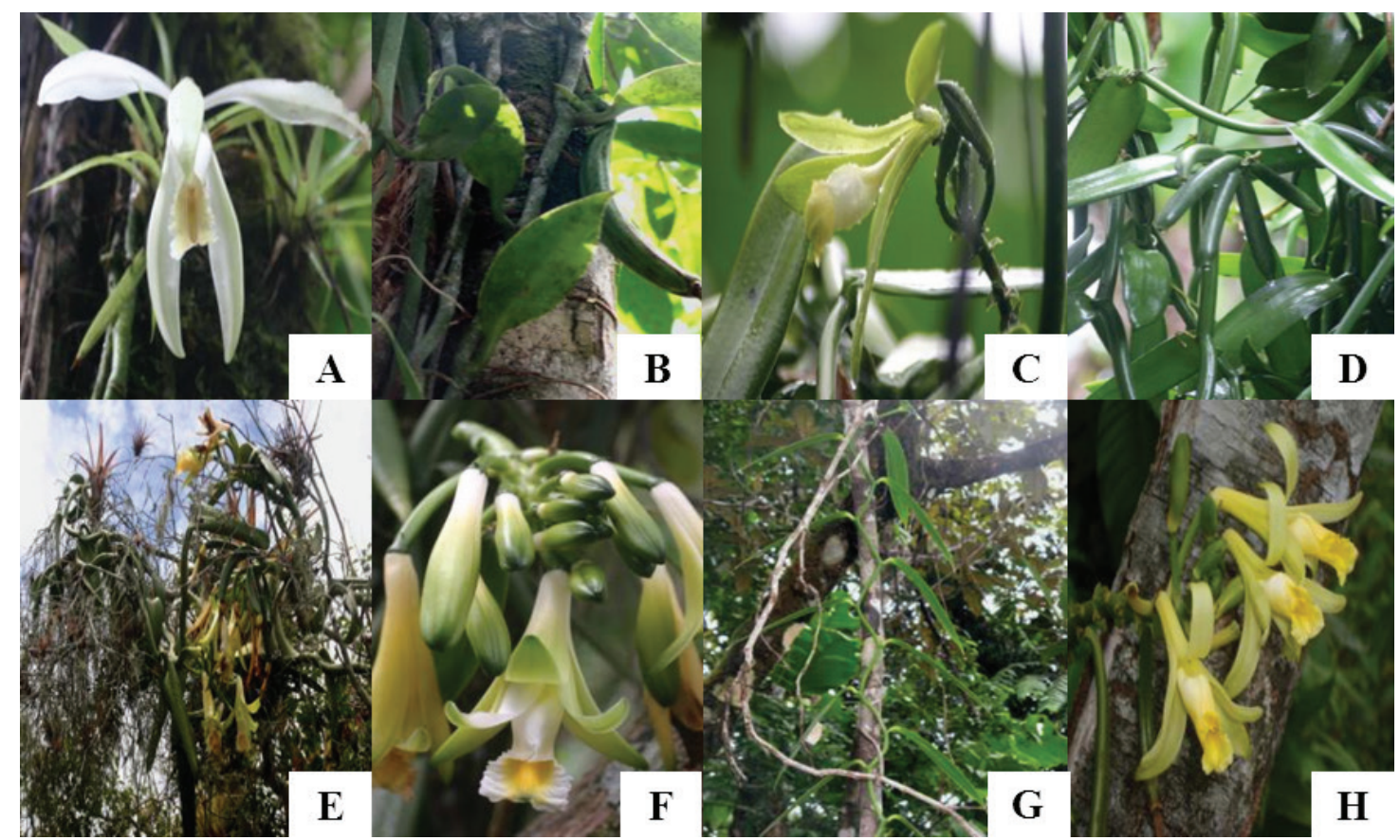

FIGURE 1. Native species of Vanilla in natural habitat in Colombia: Vanilla trigonocarpa - A. Flower, B. Developing fruit; Vanilla phaeantha - C. Flower D. Developing fruit; Vanilla calyculata - E.. habit, association with bromelias in subxerophytic shrubland. F. flower. Vanilla rivasii G. growth habit in tropical humid forest. H. inflorescence with three flowers opens simultaneously, and developing fruits. (Photos: A-G: Flanagan, 2009-2015; H: Molineros-Hurtado, 2011).

populations. The combination of small population sizes, and low genetic diversity from clonal reproduction makes these species extremely vulnerable to population, and eventual species extinction (Ellstran \& Elam 1993).

Vanilla species have a natural lowland tropical distribution. In Colombia they associate with either the humid tropical forests along the Pacific littoral and in the Amazon region, with the dry tropical forests found in the Caribbean region, the inter-Andean valleys of the Magdalena and Cauca rivers, or in the riparian forests in the 'Llanos' region of the Orinoco watershed in the Northeast of the country. Vanilla species are rarely found above 1200 masl at this latitude. Each species in Colombia tends to be limited in distribution to one or sometimes two of the five biogeographic regions: Pacific, Andean, Caribbean, Amazonia and Llanos (Table 1). Colombia contains two recognized biodiversity hotspots, The Northern Andes, and the Tumbes-Chocó-Magdalena (Myers, Mittermeier, Mittermeier, da Fonseca \& Kent, 2000), and the Chocó region on the Pacific coast harbors unparalleled plant biodiversity (Gentry, 1986). All of these habitats are under considerable threat of deforestation, due to the continued direct impact of habitat conversion for agriculture and mining (both legal and illegal), as well as the increasingly common forest fires (González et al. 2011).

In 2014, the Colombian national deforestation rate registered an increase of $14 \%$ compared with the previous year, with a total of 140,356 Ha lost. Most deforestation is occurring in the Amazon and Andean regions. Nonetheless, the tendencies in the Caribbean and Pacific regions are the more troubling for the Vanilla genus. Only 4\% of the original cover of tropical dry forest remains in Colombia (Pizano \& García 2014), and in 2014, the Caribbean region, with only $3 \%$ forest cover, constituted $14 \%$ of the total national forest loss, with a total loss of 18.903 Ha. In the Chocó biogeographic region along the Pacific littoral, which still retains a high proportion of natural forest habitat, the deforestation rate more than doubled from 2013 to 2014 (IDEAM, 2015). In the field we have found populations of eight species associated with humid forest in the Pacific region, and 
three species with distributions in tropical dry forest (Table 1). For several species only a single locality is known.

In addition to habitat degradation, orchids, being of commercial interest, are subject to the pressure of collection from wild populations (Calderón-Sáenz 2007). In Colombia, Vanilla is currently not much sought-after compared with other ornamental orchid species. However, as interest grows in its cultivation, it is likely that vines will be increasingly extracted from the wild. With species determination being problematic due to infrequent flowering, it is probable that both commercial and non-commercial species will be targeted, as has been seen in Central America and Mexico, where fewer than 30 wild plants of $V$. planifolia are known (Schluter et al. 2007).

Political strategies for Vanilla conservation in Colombia. In 2015, a National Plan for the Study and Conservation of Colombian Orchids was published (MADS \& UNAL, 2015). This document details the legal framework that exists at the national and international level for the protection of orchid species. The entire Orchidaceae family, with some exceptions, is listed in Appendix II of the CITES Convention as species that may become threatened with extinction if trade is not closely controlled. A handful of species are listed in Appendix I as threatened with extinction and requiring further protective measures. It is important to note that Appendix II of CITES exempts the "fruits, and parts and derivatives thereof, of naturalized or artificially propagated plants of the genus Vanilla". Equally, seeds, seedpods, and pollen (including pollinia), and tissue cultures obtained in vitro are also exempt.

In 2007, the Red list for Orchid species in Colombia was published (Calderón-Sáenz 2007). This volume details 375 species across the more threatened genera, with more than half being categorized within the higher risk categories of Critical (CR), Endangered (EN) or vulnerable (VU). The genus Vanilla was not assessed, and the lack of population data for these species hinders a comprehensive threat assessment. To date, only a small number of small populations are known, and it is probable that most Vanilla species in Colombia fall within a higher category of risk.

The National Plan for the Study and Conservation of Colombian Orchids aims to have all Colombian orchid species prioritized for conservation by 2025 , with Colombia recognized as a leading country for orchid conservation. Given the small, infrequent populations of Vanilla we have found in the wild, it is of considerable concern that the entire genus of Vanilla is excluded from CITES Appendix II. In particular, exempting "naturalized or artificially propagated plants of the genus Vanilla" from the Appendix II may make enforcement of wildlife regulations more difficult, as a wild-sourced plant can easily be presented as artificially propagated. With increased attention on Vanilla wild populations for commercial ventures, it may be necessary to clarify this exemption, limiting it to only the major cultivated species of $V$. planifolia, $V$. pompona, and V.x. tahitensis, with plants being exempt only if they are of certifiable artificial propagation. To improve protection for populations of Vanilla species native to Colombia, it is also important to assess these species for listing in the IUCN Red List of Threatened Species. Currently, not one species from the aromatic clade of Vanilla is listed in the IUCN. These measures will be an important step forward to achieving in Colombia, as in Mexico under the government resolution NOM-059-SEMARNAT-2010, a special protection for Vanilla biodiversity.

The Colombian National Plan details a number of actions necessary for effective conservation of the orchid diversity of the country. These measures range from continued study of taxonomy, diversity, physiology and ecology of native orchid species, establishing priorities for conservation action, including the in situ conservation of orchid populations and their habitats, the development of sustainable strategies for commercialization, and promoting awareness regarding the conservation needs in local communities.

In the face of threats from habitat degradation, and uncontrolled exploitation of wild populations, there is an urgent need for effective integrated strategies for orchid conservation. In the case of Vanilla in Colombia, these actions must be swift, to take effect before limited populations disappear from the wild. We here outline the necessary conservation actions, including in situ, ex situ and circa situm measures, and their application in the context of Vanilla conservation in Colombia. Table 2 provides an overview of these actions. 
TABLE 2. Activities for an integrated strategy for conservation and sustainable use of native Vanilla species in Colombia.

\section{Political strategies}

Evaluate the status of the whole of the genus Vanilla as exempt from CITES Appendix II.

Evaluate all species of Vanilla at the national level for inclusion in the IUCN Red List of Threatened Species.

Consider special National protection for native Vanilla species.

Develop strategies to enforce existing national and international conservation legislation, including forensic genetic tools.

Certification of authorized sustainable sources of Vanilla germplasm for commercialization.

\section{In situ conservation actions}

Gap Analysis to ensure inclusion of in situ Vanilla populations in protected area networks, as well as maximum coverage of genetic diversity in ex situ collections.

Research program on biogeography, genetic diversity, ecology, phytochemistry and physiology of Vanilla species in natural habitat.

Development of DNA Barcodes for native Vanilla species, and further genetic profiling for forensic applications.

Develop a strategy for population restoration, including population augmentation, and reintroductions, both within and beyond natural ranges.

\section{Ex situ conservation actions}

Establishment of an in-country living collection of representative genotypes, with at least two duplications.

Establishment of a cryopreserved seed bank, and associated research program to develop optimal long-term storage protocols, including synthetic seeds.

Establishment of in vitro germplasm collection, maximizing genetic diversity, and an associated research program to develop efficient protocols for ex vitro acclimatization for cultivation and population restoration.

Large-scale in vitro multiplication of certified planting material for prioritized genotypes.

Establishment of an orchid mycorrhizal and endophyte germplasm collection, and associated research into functional application of microbial symbionts in ex situ propagation, and population restoration \& cultivation.

\section{Circa situm conservation actions and sustainable use}

Evaluation of market possibilities for diversified vanilla products from distinct species, and for organic or other product certification.

Establishment of community-based circa situm cultivation initiatives, including community germplasm banks as living collections.

Characterization of native Vanilla genetic resources for traits of agronomic and market interest, including phytosanitary evaluation of plant-microbe interactions.

Capacity building for good agro-ecological practice for vanilla cultivation, pollination and post-harvest processing. 
In situ measures for Vanilla conservation. Protection of the natural habitat - both actual, and that predicted for future distributions under climate change scenarios - is the single most important conservation action for most plant species, although additional measures are also needed to ensure the survival of populations in natural habitat. In situ conservation facilitates the maintenance of a sufficient population size to retain genetic variation and viability. Additionally, it enables conservation of the ecological interactions in which the species are involved, thus also contributing to the conservation of other species in inter-dependent ecological networks. Moreover, in situ conservation permits ongoing adaptive change in response to environmental variation, thus maximizing persistence of the species in the long-term (Maxted, FordLloyd \& Hawkes, 1997). To achieve effective in situ conservation the following actions should be taken.

Continued research on Vanilla species in their natural environments - . As the National Plan for the Study and Conservation of Orchids (MADS \& UNAL, 2015) makes abundantly clear, for the vast majority of Colombian orchids, including Vanilla species, much more information is needed to develop effective conservation strategies. A broad research program is required that includes taxonomical delimitations, population distributions (both current and potential under climate change scenarios), and ecological characterization of natural habitats. In addition, studies on population biology, genetic diversity both within and between populations, and ecological interactions, in particular with pollinators, mycorrhizal fungi and seed dispersers, are needed to better understand requirements for population persistence. Furthermore, with a view to promote sustainable cultivation systems, studies aimed at understanding plant physiology under both natural and agro-ecological conditions, and for the characterization of organoleptic traits are required.

Establish distributions and determine representation in protected areas - . In order to maximize the protection given to natural plant populations it is important that their natural distributions are included within the network of in situ protected areas. In Colombia this network comprises both public and private protected areas. Our studies have found a concentration of Vanilla diversity in the Chocó biogeographic region.
This region retains $50 \%$ of native forest cover (Gillespie et al. 2012), yet less than 5\% of this area is included in the Protected Area Network (ForeroMedina \& Joppa 2010). Most of this region is covered by the autonomous territories of the indigenous and afro-descendent communities, making participative conservation initiatives with these communities key to the success of an integrated strategy for Vanilla in Colombia, as discussed below (WWF Colombia 2008).

A thorough gap analysis for the genus in the country is advisable in order to identify areas where in situ conservation measures should be prioritized, as well as to ensure that the maximum amount of genetic diversity in the country is represented in ex situ collections (Maxted, Dulloo et al. 2008). In Colombia, a single model of species distribution has been developed for Vanilla odorata, but this is limited to only the Department of the Valle del Cauca (ReinaRodriguez 2011). Given the broad distributions of many Vanilla species, this is an action that must be conducted at the national level, or above, and for all species in the genus. Our work has mainly focused on the Pacific and Andean regions of Colombia, and continued botanical studies are urgently needed in the Amazon, Llanos and Caribbean regions.

Ecological and physiological studies - Ecological studies in Vanilla are limited by the scarcity of natural populations for study, as well as the ephemeral flowering, and pollination visits. Pollination in many aromatic species is likely undertaken by male Euglossine bees (Soto-Arenas 2003, Pansarin 2016). Within the aromatic clade, Roubik and Ackerman (1987) observed bees in the genera Euglossa, Eulaema and Eufresia with pollen from $V$. planifolia, $V$. pompona, and other unidentified species. Pollination of $V$. trigonocarpa by Euglossa asarophora is reported (Soto-Arenas \& Dressler 2010), and the aromatic compound vanillin strongly attracts Eulaema cingulata (van der Cingel 2001). There is evidence of self-pollination in $V$. palmarum and V. bicolor (Householder et al. 2010; Van Dam et al. 2010), and some spontaneous self-pollination may occur in V. planifolia (Soto-Arenas 2003). In Cuba, where no Euglossine bees are present (Genaro 2008), naturalized populations of Vanilla planifolia present natural pollination events. These fruiting events may 
be the result of visits by Melipona beecheii Bennett, 1831, or from self-pollination (Angel Vale, pers. comm.). The membranaceous species, Vanilla edwallii is pollinated by males bees in the genus Epicharis (Apidae: Centridini) (Pansarin et al. 2014).

As effective pollination is needed to maintain population viability in the wild, it is vital to understand pollination biology, and take measures to also ensure the conservation of pollinator species. Furthermore, the presence of self-pollination is an agronomic trait of considerable interest, with the potential to greatly reduce the labor needed for this hand-pollinated crop. Pollination studies of native species in Colombia are lacking.

Vanilla, like all orchid species, relies on a mycorrhizal interaction with a fungal symbiont for seed germination, and subsequent plant growth, nutrition and defense. Research into this area is discussed in the ex situ section below. Physiological studies are also recommended to characterize traits of potential agronomic and commercial interest, as well as the performance of interspecific hybrids of interest. These traits should include studies of phytochemistry or organoleptic traits in order to assess market opportunities. For both conservation and cultivation, environmental characterization of habitats is also necessary for planning translocation activities.

Genetic diversity studies - . In order to implement effective conservation management and sustainable use strategies, an understanding of the structure of the genetic diversity both within and between species is recommended. While phylogenetic relationships are discernable between aromatic species using a traditional DNA sequence loci (Lubinsky et al. 2008, Soto-Arenas \& Dressler 2010, Molineros-Hurtado et al. unpubl. data), intraspecific genetic structure is less clear, with low levels of genetic variation detected within species (e.g. Schluter et al. 2007). However, new techniques in genotyping (Narum et al. 2013) offer the potential for higher resolution genetic characterization for ecological and agronomic profiling. Ideally this should be conducted across species distributions, and at the supranational level where possible.

Genetic characterization also offers effective tools for the enforcement of environmental legislation, including CITES. An important step forward in this area is the development of the DNA Barcodes for the Vanilla species native to Colombia, thus providing a necessary tool for the identification of species from vegetative material (González \& Paz 2013). A more detailed genotype dataset from next generation sequencing methods would also allow for the determination of population of origin of illegally collected material.

Population restoration - Due to the naturally small and rare populations of native Vanilla species, conservation translocation actions are advisable to maintain species in the wild. In particular translocation is recommended to more secure protected areas, including members of the network of private reserves, which often have a more restricted access than the National Parks system (Asociación Red Colombiana De Reservas Naturales De La Sociedad Civil; Resnatur.org.co).

Translocation activities may be one of four different actions. Population augmentation involves the addition of plants to an already existing population. Plants may also be reintroduced to a site where the species was previously recorded, or to a site within the species historical range, but having no previous record of presence (within range introduction). Finally, a new population may be established with conservation aims to a site beyond the recorded historical range (Liu et al. 2015). There is a particular need to apply this latter measure in the face of impact of climate change on plant species distributions.

In Colombia, we have successfully conducted population augmentation actions for Vanilla calyculata using material sourced from the same location and vegetatively propagated before re-introduction (Flanagan et al. 2012). However, further translocation actions for all aromatic species, including within range and beyond range introductions to establish populations in protected areas, should be considered. Such translocations would also encompass the objective of establishing ex situ living collections (see below). In planning conservation translocation actions, a prior study of genetic diversity is recommended to help determine appropriate sources for plant material. The application of asymbiotic or symbiotic in vitro propagation from seed (see ex situ below) offers a promising avenue to propagate material for translocation while also promoting genetic diversity. 
In in situ conservation activities, it is important that the demographic parameters of both translocated populations and natural populations should be monitored periodically to ensure ongoing population viability (Tremblay \& Hutchings, 2003).

Ex situ measures for Vanilla conservation. Although managed in situ measures represent the ideal for plant conservation, for orchids this strategy faces the challenge of the copious, uncontrolled extraction of plants from natural habitat. Thus, although the designation of protected areas and population monitoring are essential, they are not sufficient actions by themselves for orchid protection. Ex situ approaches must be implemented in a complementary manner to ensure species conservation, as also indicated in Article 9 of the Convention for Biological Diversity (Hagsater et al. 1996, Seaton et al. 2010, 2013). Furthermore, in situ activities such as reintroduction into natural habitats may require initial ex situ conservation actions, with in vitro propagation of planting material. An integrated conservation strategy must implement all of these actions for each species in order to maximize the preservation of Vanilla genetic diversity.

Ex situ conservation strategies involve the conservation of a species' genetic diversity outside of the natural habitat, through the establishment of living collections, in botanical gardens or universities, and also the preservation of genetic diversity in seed or in vitro tissue banks (Seaton \& Pritchard 2003). In the case of orchids, ex situ conservation must also incorporate compatible mycorrhizal fungi (Swarts \& Dixon 2009a), thus enhancing the efficacy of future population restoration activities.

Living collections - Plants growing in secure ex situ conditions are an important complementary action in an integrated strategy for Vanilla conservation. However, the demands of space, particularly for Vanilla plants, limit the number of individuals, or distinct genotypes that can be maintained, thus limiting the representative genetic diversity conserved. Nonetheless, living collections are a key resource for research purposes, as well as being essential for new cultivar development. This is particularly important for Vanilla given the several years' time lapse from in vitro propagation or germination to flowering. If a sufficient, albeit limited number of living plant accessions can be maintained, these can provide the material for developing methodologies for long-term germplasm conservation in cryopreservation, as well as for studies of agronomic traits, phytochemistry and plant physiology and ecology, in particular plantmicrobe interactions (see, for example, Koyyappurath et al. 2015b). The PVBMT Research Unit of CIRAD on the Island of Reunion maintains a collection of 400 living vanilla genotypes, from over 23 species, of which ten are from the aromatic clade (Roux-Cuvelier \& Grisoni 2010). Several further small collections exist outside of the natural distribution of the aromatic clade. However it is vital that ex situ conservation and research collections be established in the country of origin of the plant material.

Ideally, living collections should be replicated in-country, in at least two localities, between partner institutions, either universities, or botanical gardens, and ideally form part of a global conservation strategy for the genus. Orchid collections do exist in some of the larger botanical gardens in Colombia, yet these are mainly located beyond the natural altitudinal range for Vanilla. Species registered as present in Colombian collections are V. calyculata, V. pompona, V. planifolia and V. spp. The Jardín Botánico de Tulúa "Juan María Céspedes", in the Cauca River Valley, at approximately 1000 m.a.s.1., contains three of these species (MADS \& UNAL 2015).

For Vanilla, as for many orchids, a further possibility is to work together with local communities within the native distributions to develop circa situm community germplasm banks. This is discussed further below.

Seed banks and other cryopreservation techniques Seed conservation has been a central tenet for conservation of genetic diversity in crop plants for several decades, and for the Orchidaceae seed conservation initiatives are growing, in particular the Orchid Seed Bank Challenge in Western Australia (Swarts \& Dixon 2009a, 2009b) and the global initiative Orchid Seed Stores for Sustainable Use (OSSSU) (Seaton 2007, Seaton et al. 2010, Seaton \& Pritchard 2011).

Research suggests that many orchid seeds stored at low humidity and low to ultra-low temperature may 
maintain viability over several decades. Given the small size of seeds, this method can effectively store a good representation of genetic diversity of each species in a small space (Merritt et al. 2014, Seaton et al. 2010). Nonetheless, some seeds have much lower viabilities, even at low temperature, and there is an urgent need for more research on the physiology of orchid seed storage and regeneration, in order to develop optimal long-term storage and regeneration conditions for different species (Divakaran et al. 2006, Merritt et al. 2014, Popova et al. 2016;).

Little attention has been paid to Vanilla seed storage. Vanilla species, with their hard, waxy seed testa adapted for withstanding passage through vertebrate intestinal tracts, are most easily germinated from immature fruits (Menchaca et al. 2011). However, storage of immature seeds under cryopreservation may not be effective. The application of innovative cryopreservation techniques including seed encapsulation-dehydration and vitrification of both seeds and other material such as pollen, in vitro meristematic tissue, or protocorms needs to be more widely explored (Merritt et al. 2014, Popova et al. 2016). A comparison of cryopreservation techniques in Vanilla planifolia found droplet vitrification of apical material to be the most successful, although survival $(30 \%)$ and regeneration (10\%) success were still low (González-Arnao et al. 2009). Divakaran et al. (2006) encapsulated in vitro regenerated shoot buds and protocorms $(3-5 \mathrm{~mm})$ in $4 \%$ sodium alginate, and found these 'synthetic seeds' could be stored successfully for up to 24 months in sterile water at $22^{\circ} \mathrm{C}$. Seed conservation is clearly a priority area for Vanilla ex situ conservation research, in particular exploring the use of these established protocols in the wild relatives of cultivated Vanilla.

In vitro germplasm collection - As a complement to the maintenance of a living collection and seed banking, an in vitro germplasm bank is also recommended. Considerable research has been devoted to in vitro propagation of orchids, including Vanilla, both from seed and meristematic tissue. In vitro propagation from seed generally applies asymbiotic techniques using a complete tissue culture medium, commonly Knudson $\mathrm{C}$ or half-strength Murashige and Skoog (MS), and is widely used for massive multiplication of orchids for commercialization, private collections, or, less frequently, population re-introductions. An alternative promising area of research is symbiotic seed germination in association with known mycorrhizal fungal symbionts. This is discussed in the following section.

A number of research groups have developed protocols for in vitro propagation of Vanilla planifolia from meristematic tissue (e.g. Divakaran et al. 2006; Tanet al. 2010). For the efficient maintenance of an in vitro germplasm bank, techniques for cultivation under slow growth conditions are necessary. An in vitro collection of genotypes has a much smaller space requirement than an ex vitro living plant collection. However, in vitro plantlets are not subject to the physiological pressures present in the natural environment, and research is needed to ensure adequate acclimatization of plants on transfer to ex vitro conditions. The application of mycorrhizal fungi to enhance nutrition and plant defenses upon extraction from in vitro conditions offers a promising line of research (Zettler et al. 2007, and see below).

Once established, meristematic tissue from in vitro culture can be used as material for encapsulation protocols for cryopreservation, as mentioned above (Popova et al. 2016, Divakaran et al. 2006). In vitro propagation also offers an efficient way to propagate selected material for both commercial cultivation and reintroduction. This is particularly important in Colombia, where the early availability of high-quality in vitro certified planting stock before large commercial ventures are initiated, may help to minimize the pressures on natural populations.

Conservation and applications of mycorrhizal fungi and other endophytes - Vanilla species, like all orchids, have a specific association with mycorrhizal fungi, which are required for seed germination and plant growth (Bayman, Mosquera-Espinosa \& PorrasAlfaro 2011, Porras-Alfaro \& Bayman 2007). Orchid mycorrhizal fungi and other endophytes likely also play a role in plant defense, either directly through antagonistic interactions, or indirectly through improved nutrition (Mosquera-Espinosa, Bayman \& Otero 2010; Otero, Mosquera-Espinosa \& Flanagan 2013).

A study of Vanilla mycorrhizal fungi in Puerto Rico and Costa Rica isolated three sexual fungal genera, 
Thanatophorus, Ceratobasidium and Tulasnella in the order Cantharellales, from both wild and cultivated adults plants of $V$. planifolia, and two other species (Porras-Alfaro \& Bayman 2007). However, only isolates of Ceratobasidium proved effective for promoting $V$. planifolia seed germination, supporting the hypothesis that orchid mycorrhizal associations may change during plant growth and development. Further, Ceratobasidium fungi isolated from another orchid species, Ionopsis utricularioides were even more effective at inducing Vanilla seed germination. These cross-species Ceratobasidium isolates were also most efficient at promoting growth and survival of in vitro plantlets of a commercial cultivar. In Colombia, both Ceratobasidium and Tulasnella spp. have been isolated from adult plants of several Vanilla species distributed across dry and humid tropical forest habitats (Mosquera-Espinosa et al. 2010, 2013; MosqueraEspinosa et al., unpubl. data), revealing a consistent relationship between adult plants of Vanilla species and these fungal genera. However, further research is required regarding mycorrhizal fungal function for in vitro seed germination and plantlet growth. For this, the use of in situ seed baits offers a promising technique to isolate those fungi with which the seeds associate for germination under natural conditions (Brundrett et al. 2003, Zettler et al. 2011).

Effective regeneration of plants from ex situ germplasm storage requires that these essential fungal symbionts are also conserved. Cryopreservation techniques have been developed to store mycorrhizal fungi either together with orchid seed (e.g. Wood et al. 2000), or separately (Batty et al. 2001, Ercole et al. 2013). Isolates of Tulasnella and Ceratobasidium genera stored at $-80^{\circ} \mathrm{C}$ for up to 24 months retained or even improved their ability to promote in vitro seed germination (Ercole et al. 2013). It is essential that ex situ germplasm storage of mycorrhizae be implemented alongside Vanilla seed storage to ensure the success of long-term ex situ conservation initiatives.

While most attention has been paid to mycorrhizal fungi, other endophytes, both fungal and bacterial, may play beneficial roles in Vanilla ecology and cultivation (Porras-Alfaro \& Bayman 2011). Endophytic fungi, including those involved in mycorrhizal associations are promising antagonistic agents for crop pathogen control, reducing the use of agrochemicals and making production systems more eco-efficient (eg. MosqueraEspinosa et al. 2013). In a study of endophytic fungi of five Vanilla species in Colombia, we found a high diversity of fungi, with 148 Operational Taxonomic Species (OTUs) belonging to eleven Ascomycete and four Basiomycete orders (Mosquera-Espinosa et al. Unpubl. data). The evaluation of functional traits of this microbial diversity is now required. The bacterium, Bacillus amyloliquefaciens, which has in vivo antifungal properties in other plant species, has been isolated from $V$. planifolia tissues (White et al. 2014). In a study of endophyte communities of fruits in cultivated vanilla, Khoyratty et al. (2015) concluded that fungal endophytes may play an important role in the development of organoleptic properties.

The study of the ecology and physiology of endophyte communities in Vanilla is an incipient, yet significant area of research. The diversity of wild populations known in Colombia offers a valuable opportunity to study naturally occurring endophytic communities, and at the Pontificia Universidad Javeriana in Cali current research activities are focused on developing an effective ex situ conservation strategy for the Vanilla Endophyte Collection, as well as evaluating these valuable microbial resources for beneficial actions in the conservation, sustainable use and phytosanitary protection of the diversity of native Vanilla species in Colombia.

\section{Circa situm conservation and sustainable use.}

In Colombia, indigenous and afro-descendent communities living in rural areas have autonomous jurisdiction over their traditional territories. The majority of the Pacific Chocó region falls within these collective jurisdictions, which also include autonomous determination for the use of the biological resources within the territories. Thus, in the Chocó region, and other areas with collective territories, any actions for the conservation and sustainable use of the native vanilla resources must be carried out in a participative manner with local communities.

Given the limitations of both in situ and $e x$ situ approaches, and the autonomy of these rural communities, a circa situm conservation system may offer a further complementary conservation strategy. Circa situm conservation refers to conservation actions within altered agricultural landscapes (e.g., 
agroforestry systems or home gardens) outside natural habitats but within a species' native geographical range (Dawson et al. 2013).

In Colombia we have worked with the community of Atuncela, a locality within the range of Vanilla calyculata in the Western Andean Cordillera to develop a community germplasm collection (Flanagan et al. 2012; Mosquera-Espinosa et al. 2012). This has involved the documentation of the different populations within the locality, and a planned strategy for ex situ vegetative propagation. Within-range population augmentation in remaining native forest fragments was also conducted. It is important that this initiative is now repeated in other localities for other Vanilla species native to Colombia; however such activities have a high investment of time due to the need for a close accompaniment for the community members.

Although there is no tradition of vanilla cultivation in the country, the market value of the crop offers these often forest-dependent communities a potential income for sustainable livelihood improvement. Vanilla plants can be easily incorporated into agroforestry systems, whether in humid tropical forest with the species such as V. planifolia or V. rivasii (Molineros-Hurtado 2012), or tropical dry forest with species such as $V$. calyculata (Flanagan et al. 2012).

However, given the fluctuating global price for vanilla, a more constant income may be ensured through the implementation of market product diversification, including the commercialization of fruits from different species with different organoleptic properties, as well as considering certification for organic or sustainable agricultural production, or 'biodiversity-friendly' cultivation. These commercial possibilities should be evaluated from the outset. Additionally, increasing awareness within the national market of the advantages of natural vanilla compared with the synthetic vanillin flavoring, could promote demand at the national level, rather than depending on the international market. The high initial investment, and a slow return can make establishing communitybased cultivation initiatives a big challenge (SotoArenas 2006), although it offers many advantages for conservation programs.

Community-based cultivation initiatives promote appreciation amongst the community of the value of the Vanilla resources in their territories, thereby encouraging community conservation actions for Vanilla, as well as promoting the more biodiverse agro-forestry ecosystems in which the vanilla is cultivated. Circa situm conservation through sustainable cultivation also minimizes the loss of beneficial ecological interactions, including those with pollinators and microorganisms. Furthermore, the generation of an additional income source may alleviate current pressures on communities to resort to unsustainable means for income generation, such as timber extraction, or land clearance for cattle grazing.

The challenges faced in implementing programs for sustainable production and on-farm conservation include the need for technical training and accompaniment in effective eco-agricultural practice, for at least the duration of the initial crop establishment period of two to three years. Training is also required in manual pollination to augment production, and in the post-harvest curing process. With no tradition of vanilla cultivation in Colombia, the establishment of a regional network together with other communitybased producers in countries such as Mexico could facilitate the capacity-building for vanilla cultivation in Colombia.

Research on plant-microbe interactions for eco-efficient cultivation - Worldwide, commercial production of vanilla is severely affected by phytosanitary problems, in particular root and stem rot caused by the fungal pathogen, Fusarium oxysporum f. sp. radicis-vanillae (Koyyappurath et al. 2015a) with a high specificity and pathogenicity to vanilla cultivars (Pinaria, Liew \& Burgess, 2010). Once infested, the elimination of this fungus from cultivation soils is extremely difficult (Hernández-Hernández, 2011). Recent studies have shed light on the physiological basis for resistance to this pathogen, highlighting accessions with resistance traits (Koyyappurath et al. 2015b). However research into plant-microbe interactions in wild populations of Vanilla may facilitate the development of further strategies for disease control, as well as understanding of processes of adaptation to new agroecological conditions, including under predicted climate change scenarios.

Endophytes, including mycorrhizal fungi are promising antagonistic agents for pathogen control 


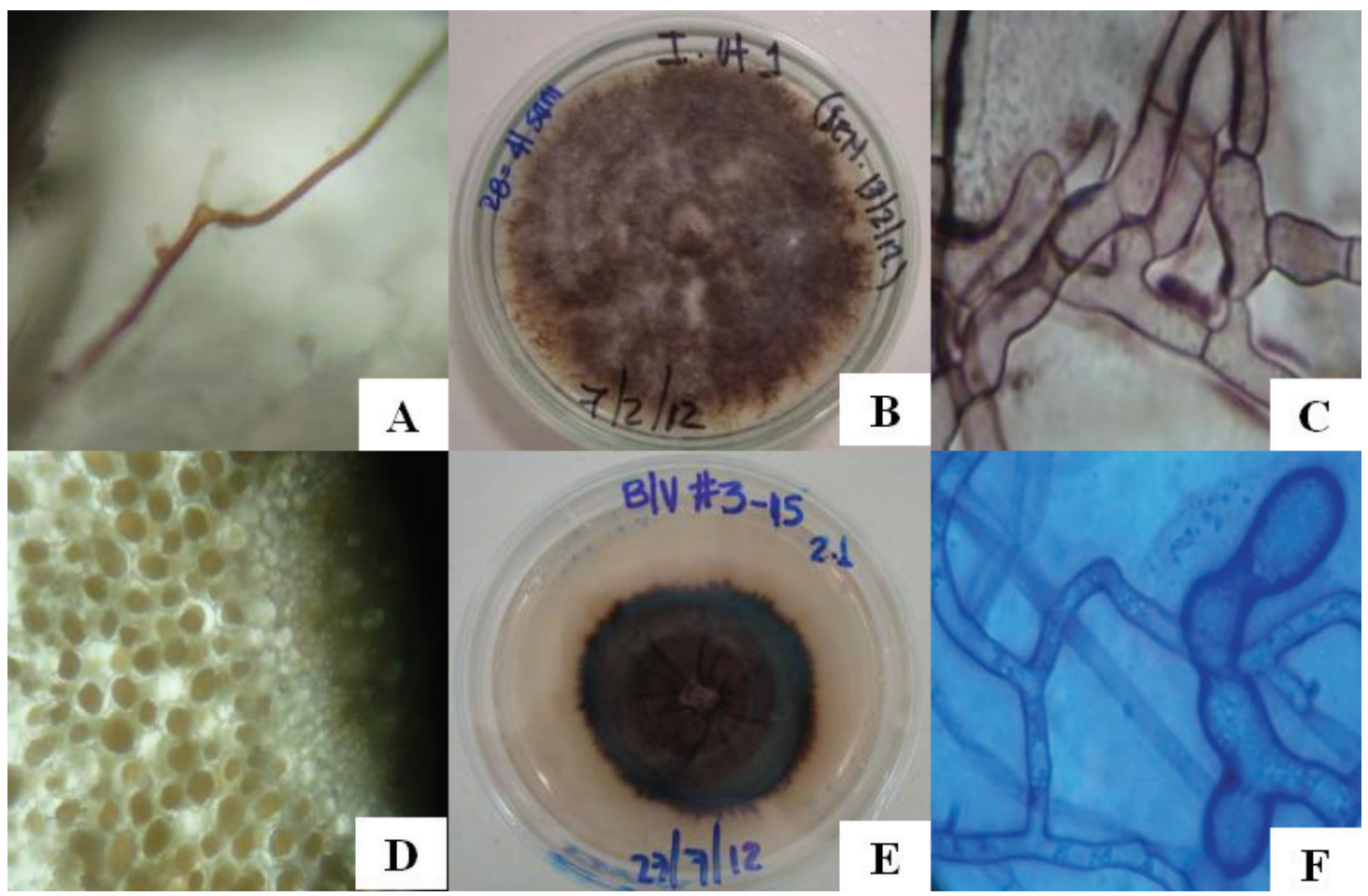

FIGURE 2. Dark Septate Endophytes (DSEs) and Orchid Mycorrhizal Fungi (OMF) present in host roots. A. DSE hyphae in rhizoplane 40X. B. Dark pure culture of DSE. C. DSE Septate hyphae 40X. D. OMF hyphae forming peloton in cortex 40X. E. Dark pure culture of OMF. F. OMF Septate hyphae, showing right angles and monilioid cells 40X. (Photos: Mosquera-Espinosa, 2012-2015).

and may also act to induce pathogen resistance in the plant (Bayman et al. 2011). Mosquera-Espinosa et al. (2013) obtained isolates of Ceratobasidium spp. from mycorrhizal pelotons present in roots of a number of orchid species in Colombia. When these were inoculated onto experimental rice plants that were then infected with the soil pathogen Rhizoctonia solani, the plants showed a significantly reduced expression of pathogenicity, indicating that the Ceratobasidium spp. can induce pathogen resistance in the plant host.

Other endophytic fungi that colonize roots in either an inter- or intra-cellular manner likely have functions related to the transfer of nutrients and disease resistance. A fungal group in which such functions have been documented include the so-called 'Dark-Septate Endophytes' (DSE). These fungi in the phylum Ascomycota, characterized by melanized, septate hyphae, are almost ubiquitous within plants, and are often found associated with mycorrhizal fungi, pathogens and other endophytes (Jumpponen \& Trappe 1998, Porras-Alfaro \& Bayman 2011). From morphological characters, DSEs can be confused with mycorrhizal fungi. DSEs are known to be highly efficient in decomposition of organic material, and may pass these nutritional resources to a host plant in an endophytic interaction, thus stimulating host growth and disease resistance (Caldwell et al. 2000). Fungi in this group have been found to be associated with wild plants of native Vanilla species in the Colombian pacific region (Mosquera-Espinosa, unpubl. data) (Fig. 2). While research has been conducted on the diversity and seed germination function of Vanilla mycorrhizal fungi, there is clearly much more to be understood regarding the role of orchid mycorrhizal fungi and other endophytes, both fungal and bacterial, in both disease resistance and plant nutrition (MosqueraEspinosa et al. 2012, Porras-Alfaro \& Bayman 2011). In Colombia, in small scale, incipient vanilla cultivation systems, endemic plant disease has not yet 
proved to be a problem. In our studies of endophytic fungal communities in natural populations we have not detected the presence of Fusarium oxysporum $\mathrm{f}$. sp. radicis-vanillae, although Fusarium solani has been identified (Mosquera-Espinosa et al. unpubl. data). It is important to attempt to maintain the absence of the major pathogens from these vanilla systems through the implementation of good agricultural practices, taking into consideration specific aspects of the plant material used, and the local environmental conditions.

In order to successfully establish sustainable community-based cultivation systems avoiding the negative cycles of pathogen infestation and increased agrochemical use, a research program in Vanilla agroecology is necessary. Agronomic characterization is required at the inter and intra-specific level for traits relating to organoleptic properties, crop yield, the physiological processes involved in flowering and pollination, including self-pollination, as well as functional traits related to plant performance with respect to biotic and abiotic stressors. These studies are also of relevance to vanilla cultivation systems worldwide.

The high diversity of wild Vanilla species in Colombia offers an excellent opportunity to understand Vanilla ecology and physiology under natural conditions. However it is essential that a program of agronomic research goes hand in hand with an effective strategy for conservation, integrating across in situ, ex situ, and circa situm measures.

Conclusion. Colombia is moving forward with biodiversity conservation strategies, and a growing community of researchers, conservation professionals, cultivators and hobbyists are dedicated to promoting orchid conservation. Within the Orchidaceae, the diversity and ecology of Vanilla has historically been under-researched, despite its economic importance. In Colombia, the Chocó biogeographic region, with the highest number of reported species for the country, is the region with the lowest coverage of protected areas. Given the increasing deforestation rates, in addition to a growing awareness of the economic potential of Vanilla species in the country, and thus increased pressure for unsustainable extraction from natural habitats, we suggest that Vanilla should receive priority action for conservation, and be considered a flagship species for the conservation and sustainable use of orchid diversity in the country, and in the Chocó region in particular. Effective preservation of the diversity of Vanilla in the country requires an integrated strategy for conservation, developing in concert measures for in situ, ex situ and circa situm conservation, and working together with local communities to develop participative programs for conservation and sustainable use. In the Pontificia Universidad Javeriana in Cali, together with institutional and community partners at the national and regional level, we have initiated a program of actions for research and outreach for both the conservation and the sustainable use of the Vanilla diversity of Colombia.

ACKNOWLEDGMENTS. The authors thank the Research Office of the Pontificia Universidad Javeriana, Cali for financial support for the Vanilla Research Program for Conservation and Sustainable Use. We also thank Don Alvaro Rivas from the community of Zacharias, Buenaventura, Valle del Cauca and Don Norman Castro, from the community of Atuncela, Dagua, Valle del Cauca for their enthusiasm for Vanilla conservation and sustainable use. We thank Francisco Molineros-Hurtado for permission to use his photograph of Vanilla rivasii.

\section{Literature Cited}

Batty, A.L., Dixon, K.W., Brundrett, M. \& Sivasithamparam, K. (2001). Long-term storage of mycorrhizal fungi and seed as a tool for the conservation of endangered Western Australian terrestrial orchids. Australian Journal of Botany, 49, 619-28.

Bayman, P., Mosquera-Espinosa A.T. \& Porras-Alfaro, A. (2011). Mycorrhizal Relationships of Vanilla and Prospects for Biocontrol of Root Rots. In: Handbook of Vanilla Science and Technology (pp. 266-279), First Edition. Edited by Daphna Havkin-Frenkel and Faith C. Belanger.

Belanger, F.C. \& Havkin-Frenkel, D. (2011). Molecular Analysis of a Vanilla hybrid cultivated in Costa Rica. In: Handbook of Vanilla Science and Technology (pp. 256-265), First Edition. Edited by Daphna HavkinFrenkel and Faith C. Belanger.

Bory, S., Lubinsky, P., Risterucci, A. M., Noyer, J. L., Grisoni M., Duval M. F. \& Besse, P. (2008). Patterns 
of introduction and diversification of Vanilla planifolia (Orchidaceae) in Reunion Island (Indian Ocean). American Journal of Botany, 95(7), 805-815.

Brundrett, M., Scade, A., Batty, A.L., Dixon K.W. \& Sivasithamparam, K. (2003). Development of in situ and ex situ seed baiting techniques to detect mycorrhizal fungi from terrestrial orchid habitats. Mycological Research, 107, 1210-1220. doi:10.1017/ S0953756203008463.

Calderón-Sáenz, E. (ed). (2007). Libro Rojo de Plantas de Colombia. In: Volumen 6. Orquídeas primer parte. Instituto Alexander von Humboldt-Ministerio de Ambiente, Vivienda y Desarrollo Territorial. Bogotá. 828 p.

Caldwell, B.A., Jumpponen, A. \& Trappe, J.M. (2000). Utilization of major detrital substrates by dark-septate, root endophytes. Mycologia, 92, 230-32.

Dawson, I.K., Guariguata, M.R., Loo, J., Weber, J.C., Lengkeek, A., Bush, D., Cornelius, J., Guarino, L., Kindt, R., Orwa, C., Russell, J. \& Jamnadass, R. (2013). What is the relevance of smallholders' agroforestry systems for conserving tropical tree species and genetic diversity in circa situm, in situ and ex situ settings? A review. Biodiversity and Conservation, 22 (2), 301-324.

Divakaran, M., Nirmal, B.K. \& Peter, K.V. (2006). Conservation of Vanilla species in vitro. Science Horticultural, 1109, 175-180.

Ellstrand, N.C. \& Elam, D. R. (1993). Population Genetic Consequences of Small Population Size: Implications for Plant Conservation. Annual Review of Ecology and Systematics, 24, 217-242.

Ercole, E., Rodda, M., Molinatti, M., Voyron, S., Perotto, S. \& Girlanda, M. (2013). Cryopreservation of orchid mycorrhizal fungi: A tool for the conservation of endangered species. Journal of Microbiological Methods, 93, 134-7.

Flanagan, N.S., Otero J.T., Molineros F.H., MosqueraEspinosa A.T, et al. (2012). Aprovechamiento sostenible de Recursos Biológicos Nativos del Distrito de Manejo Integrado de Atuncela. Guía Práctica. Cartilla de los Recursos Biológicos del Distrito de Manejo Integrado de Atuncela. Proyecto de CVC No 0051 y la Pontificia Universidad Javeriana-Cali. 31p.

Forero-Medina, G., \& Joppa, L. (2010). Representation of global and national conservation priorities by Colombia's protected area network. Plos One, 5(10), e13210.

Genaro JA. (2008). Origins, composition and distribution of the bees of Cuba (Hymenoptera: Apoidea: Anthophila). Insecta Mundi 52: 1-16.

Gentry, A.H. (1986). Species Richness and Floristic Composition of Choco region plant communities. Caldasia 15, 71-91.

Gillespie, T. W., Lipkin, B., Sullivan, L., Benowitz, D. R.,
Pau, S., \& Keppel, G. (2012). The rarest and least protected forests in biodiversity hotspots. Biodiversity and Conservation, 21(14), 3597-3611.

González, J.J., Etter, A.A., Sarmiento, A.H., Orrego, S.A., Ramírez, C., Cabrera, E., Vargas, D., Galindo, G., García, M.C. \& Ordoñez, M.F. (2011). Análisis de tendencias y patrones espaciales de deforestación en Colombia. Instituto de Hidrología, Meteorología y Estudios Ambientales-IDEAM. Bogotá D.C., Colombia. $64 \mathrm{p}$.

González, M. \& Paz, A. (2013). iBOL Colombia advances: Barcoding life in a megadiverse country. Barcode bull, 4 (2), 6.

González-Arnao M.T., Lázaro-Vallejo, C.E., Engelmann, F., Gómez-Pastrana, R., Martínez-Ocampo, Y.M., Pastelin-Solano, M.,C., et al. (2009). Multiplication and cryopreservation of vanilla (Vanilla planifolia 'Andrews'). In Vitro Cellular \& Developmental Biology - Plant-Springer, 45, 574-82.

Hagsater, E., Dumont, V. \& Pridgeon, A.M. (1996). Orchids. Status survey and conservation action plan. IUCN, Gland, Switzerland. 84 p.

Hernández-Hernández, J. (2011). Vanilla diseases. In: Handbook of Vanilla Science and Technology (pp. 2639), First Edition. Edited by Daphna Havkin-Frenkel and Faith C. Belanger.

Householder, E., Janovec, J., Balarezo Mozambite, A., Huinga Maceda, J., Wells, J.\& Valega, R. (2010). Diversity, natural history, and conservation of Vanilla (Orchidaceae) in Amazonian wetlands of Madre De Dios, Peru. Journal of the Botanical Research Institute of Texas, 4, 227 - 243.

Instituto de Hidrología, Meteorología y Estudios Ambientales de Colombia (IDEAM). (2015). Consulted 2-01-2016. http://www.ideam.gov.co/web/sala-deprensa/noticias/-/asset_publisher/96oXgZAhHrhJ/ content/aumenta-deforestacion-en-colombiapara-2014.

Jumpponen, A. \& Trappe, J.M. (1998). Dark septate endophytes: a review of facultative biotrophic rootcolonizing fungi. New Phytologist, 140, 295-310

Koch, A.K., Fraga, C.N., Santos, J.U.M. \& Ilkiu-Borges, A.L. (2013). Taxonomic Notes on Vanilla (Orchidaceae) in the Brazilian Amazon, and the Description of a New Species. Systemetic Botany, 38 (4), 975-981.

Khoyratty, S., Dupont, J. , Lacoste, S., Palama, T. ,Choi, Y ., Kim, H., et al. (2015). Fungal endophytes of Vanilla planifolia across Reunion Island: isolation, distribution and bio transformation. BMC Plant Biology, 15, 19. doi: 10.1186/s12870-015-0522-5

Koyyappurath, S., Atuahiva, T., Le Guen, R., Batina, H., Le Squin, S., Gautheron, N., Edel Hermann, V., Peribe, J., Jahiel, M., Steinberg, C., Liew, E. C. Y., Alabouvette, C., 
Besse, P., Dron, M., Sache, I., Laval, V. \& Grisoni, M. (2015a). Fusarium oxysporum f. sp. radicis-vanillae is the causal agent of root and stem rot of vanilla. Plant Pathology, 65, 12445. doi: 10.1111/ppa.12445

Koyyappurath, S., Conéjéro, G., Dijoux, J.B., LapeyreMontès, F., Jade, K., Chiroleu, F., Gatineau, F., Verdeil, J.L., Besse, P. \& Grisoni, M. (2015b). Differential Responses of Vanilla Accessions to Root Rot and Colonization by Fusarium oxysporum f. sp. radicisvanillae. Frontiers in Plant Science, 6, 1125. doi: 10.3389/fpls.2015.01125

Liu, H., Ren, H., Liu, Q., Wen, X., Maunder, M. and Gao, J. (2015). Translocation of threatened plants as a conservation measure in China. Conservation Biology, 29, 1537-1551. doi: 10.1111/cobi.12585

Lubinsky, P., Cameron, K.M., Molina, M.C., Wong, M., Lepers Andrzejewski, S., Gómez-Pompa, A. \& Kim S.C. (2008). Neotropical roots of a Polynesian spice: the hybrid origin of Tahitian vanilla, Vanilla tahitensis (Orchidaceae). American Journal of Botany, 95, 1040 1047.

Maxted, N., Ford-Lloyd, B. V. and Hawkes, J. G. (Eds). (1997). Plant conservation: The in situ approach. London: Chapman and Hall. 446 p.

Maxted, N., Dulloo, E., Ford-Lloyd, B.V., Iriondo, J.M., Jarvis, A. (2008) Gap analysis: a tool for complementary genetic conservation assessment. Diversity and Distributions, 14(6), 1018-1030.

Menchaca, R., Ramos, J.M., Moreno, D., Luna, M., Mata, M., Vázquez, L.M. \& Lozano, MA. (2011). Germinación in vitro de híbridos de Vanilla planifolia y $V$. pompona. Revista colombiana de biotecnología. 13(1), 80-84.

Merritt, J.D., Hay, F.R., Swarts, N.D., Sommerville, K.D. \& Dixon, K.W. (2014). Ex Situ Conservation and Cryopreservation of Orchid Germplasm. International Journal of Plant Sciences, 175(1), 46-58.

Ministerio de Ambiente y Desarrollo Sostenible y Universidad Nacional de Colombia (MADS \& UNAL. (2015). Plan para el estudio y la conservación de las orquídeas en Colombia. Textos: Betancur, J., Sarmiento, H., Toro-González, L. \& Valencia, J. Universidad Nacional de Colombia. Facultad de Ciencias. Instituto de Ciencias Naturales; Coord. Técnica: Higuera Díaz, Diego - Minambiente. Dirección de Bosques, Biodiversidad y Servicios Ecosistémicos Bogotá D.C.: Colombia. Ministerio de Ambiente y Desarrollo Sostenible; Universidad Nacional de Colombia. 336 p. Molineros-Hurtado, F.H, González-Mina, R.T., Flanagan, N.S. \& Otero, J.T. (2014). Vanilla rivasii (Orchidaceae), a new species from the Colombian pacific region. Lankesteriana, 13(3), 353-357.

Molineros-Hurtado, F.H. (2012). Caracterización morfológica y filogenia del género Vanilla en el distrito de Buenaventura-Valle del Cauca (Colombia). Tesis de Maestría en Ciencias Biológicas, Línea de Investigación Recursos Fitogenéticos Neotropicales. Universidad Nacional de Colombia, sede Palmira. 157 p.

Mosquera-Espinosa, A.T., Bayman, P. \& Otero, J.T. (2010). Ceratobasidium como hongo micorrízico de orquídeas en Colombia. Acta Agronómica, 59, 316-326.

Mosquera-Espinosa, A.T., Otero, J.T., Molineros, F., Vásquez, E. \& Flanagan, N.S. (2012). Bioprospección de los recursos nativos de la orquídea Vanilla Spp. presente en el Valle del Cauca. Acta Agronómica, 52(Especial), 37-38.

Mosquera-Espinosa A.T., Bayman, P., Prado,G., GómezCarabalí, A. \& Otero, J.T. (2013). The double life of Ceratobasidium: orchid mycorrhizal fungi and their potential for biocontrol of Rhizoctonia solani sheath blight of rice. Mycologia, 105, 141-150.

Myers, N., Mittermeier, R.A., Mittermeier, C.G., da Fonseca, G.A.B. \& Kent, J. (2000). Biodiversity Hotspots for Conservation Priorities. Nature, 403, 853-858.

Narum, S.R., Buerkle, C.A., Davey, J.W., Miller, M.R., Hohenlohe, P.A. (2013). Genotyping-by-sequencing in ecological and conservation genomics. Molecular Ecology, 22, 2841-7.

Ortiz-Valdivieso, P. (2015). Vanilla. In: R. Bernal, S.R. Gradstein \& M. Celis (Ed.). Catálogo de plantas y líquenes de Colombia. Instituto de Ciencias Naturales, Universidad Nacional de Colombia, Bogotá. http:// catalogoplantascolombia.unal.edu.co

Otero, J.T., Mosquera-Espinosa, A.T. \& Flanagan, N.S. (2013). Tropical orchid mycorrhizae: Potential applications in orchid conservation, commercialization, and beyond. Lankesteriana 13(1-2), 57-63.

Pansarin E.R. (2016). Recent advances on evolution of pollination systems and reproductive biology of Vanilloideae (Orchidaceae). Lankesteriana this volume

Pansarin, E. R., Aguiar, J. M. R. B. V. \& Ferreira, A. W. C. (2012). A new species of Vanilla (Orchidaceae: Vanilloideae) from São Paulo, Brazil. Brittonia (Bronx, N.Y.), 64, 157-161.

Pansarin, E.R., Aguiar, J.M.R.B.V., Pansarin, L.M. (2014). Floral biology and histochemical analysis of Vanilla edwallii Hoehne (Orchidaceae: Vanilloideae): an orchid pollinated by Epicharis (Apidae: Centridini). Plant Species Biology, 29, 242-252. doi:10.1111/14421984.12014

Pansarin E.R. \& Miranda M.R. (2016). A new species of Vanilla (Orchidaceae: Vanilloideae) from Brazil. Phytotaxa 267, 084-088.

Pinaria A.G., Liew, E.C.Y. \& Burgess, L.W. (2010). Fusarium species associated with vanilla stem rot in Indonesia. Australasian Plant Pathology, 39, 176-183. 
Pizano, C. \& García H. (2014). El Bosque Seco Tropical en Colombia. Instituto de Investigación de Recursos Biológicos Alexander von Humboldt (IAvH). Bogotá, D.C. Colombia. 213 p.

Popova, E., Kim H.H., Saxena P.K., Engelmann, F. \& Pritchard, H.W. (2016). Frozen beauty: The cryobiotechnology of orchid diversity. Biotechnology Advances. doi: 10.1016/j.biotechadv.2016.01.001

Porras-Alfaro, A. \& Bayman, P. (2007). Mycorrhizal fungi of Vanilla: diversity, specificity and effects on seed germination and plant growth. Mycology, 99(4), 510 525.

Porras-Alfaro, A. \& Bayman, P. (2011). Hidden Fungi, Emergent Properties: Endophytes and Microbiomes. Annual Review Phytopathology, 49, 291-315.

Ranadive, A.S. (2011). Quality control of Vanilla beans. In: Handbook of Vanilla Science and Technology (pp.141161), First Edition. Edited by Daphna Havkin-Frenkel and Faith C. Belanger.

Reina-Rodríguez, G.A (ed.). (2011). Vanilla odorata. (pp. 45-55). En: Planes de manejo para la conservación de 22 especies focales de plantas en el departamento del Valle del Cauca, Cali, Colombia. 258p.

Roubik, D. W. \& Ackerman, J. D. (1987). Long-term ecology of euglossine orchid bees (Apidae: Euglossini) in Panama. Oecologia, 73, 321-333.

Roux-Cuvelier, M. \& Grisoni, M. I. (2010). Conservation and movement of Vanilla germplasm. In: Odoux, E. \& Grisoni, M. (Ed.), Vanilla (pp. 31-41). Boca Ratón, FL: CRC Press.

Salazar-Rojas, V.M., Herrera-Cabrera, B.E., DelgadoAlvarado, A., Soto-Hernández, M., Castillo-González, F. \& Cobos-Peralta, M. (2011). Chemotypical variation in Vanilla planifolia Jack. (Orchidaceae) from the Puebla- Veracruz Totonacapan region. Genetic Resources and Crop Evolution, 59, 875-887.

Schluter, P.M., Soto-Arenas, M.A. \& Harris, S.A. (2007). Genetic variation in Vanilla planifolia (Orchidaceae). Economic Botany, 61, 328-336.

Seaton, P. \& Pritchard, H.W. (2003). Orchid germplasm collection, storage and exchange (pp. 227-258). En: Dixon, K.W., S.P Kell, R.I Barrett \& P.J. Cribb (eds.). Orchid conservation. Natural History Publications, Borneo.

Seaton, P.T. (2007). Establishing a global network of orchid seed banks. Lankesteriana, 7, 371-375.

Seaton, P.T., Hu, H., Perner, H. \& Pritchard, H.W. (2010). Ex situ conservation of orchids in a warming world. Botanic Review, 76, 193-203.

Seaton, P. \& Pritchard, H. (2011). Orchid seed stores for sustainable use. Lankesteriana, 11, 349-353.

Seaton, P., Kendon, J. P., Pritchard, H.W., Puspitaningtyas, D. M. \& Marks, T.R. (2013). Orchid conservation: the next ten years. Lankesteriana, 13(1-2), 93-101.

Soto-Arenas, M.A. (2003). Vanilla. In: Pridgeon, A. M., Cribb, P. J., Chase, M. W. \& Rasmussen F. N. [eds.]. (2003). Genera orchidacearum: Orchidoideae (pp. 321- 334). Oxford University Press, New York, New York, USA.

Soto-Arenas, M.A. (2006). La vainilla: retos y perspectivas de su cultivo. CONABIO. Biodiversitas, 66, 1-9.

Soto-Arenas, M.A. \& Cribb, P. (2010). A new infrageneric classification and synopsis of the genus Vanilla Plum. Ex Mill. (Orchidaceae: Vanillinae). Lankesteriana, 9, 355-398.

Soto-Arenas, M.S., Dressler, R.L. (2010). A revision of the Mexican and Central American species of Vanilla Plumier ex Miller with a characterization of their ITS region of the nuclear ribosomal DNA. Lankesteriana, 9, 285-354.

Swarts, N. D. \& Dixon, K. W. (2009a). Perspectives on orchid conservation in botanic gardens. Trends in Plant Science, 14, 590-598.

Swarts, N. D. \& Dixon, K. W. (2009b). Terrestrial orchid conservation in the age of extinction. Annals of Botany, 104, 543-556.

Tan, B.C., Chin, C.F. \& Alderson, P. (2010). Optimization of plantlet regeneration from leaf and nodal derived callus of Vanilla planifolia Andrews. Plant Cell Tissue Organ Culture, 105, 457-463.

Tremblay, R.L. \& Hutchings, M.J. (2003). Population dynamics in orchid conservation: a review of analytical methods, based on the rare species Lepanthes eltoroensis. (pp. 183-204). En: Dixon, K.W., S.P Kell, R.I Barrett \& P.J. Cribb (eds.). Orchid conservation. Natural History Publications, Borneo.

Van Dam, A. R., Householder, J. E. \& Lubinsky, P. (2010). Vanilla bicolor Lindl. (Orchidaceae) from the Peruvian Amazon: autofertilization in Vanilla and notes on floral phenology. Genetic Resources and Crop Evolution, 57, 473-480.

van der Cingel, N.A. (2001). An atlas of orchid pollination: America, Africa, and Australia. A. A. Balkema, Rotterdam, Netherlands.

White, J. F., Torres, M.S., Sullivan, R.F., Jabbour, R. E., Chen, Q., Tadych, M., Irizarry, I., Bergen, M.S., HavkinFrenkel, D. \& Belanger, F.C. (2014). Occurrence of Bacillus amyloliquefaciens as a systemic endophyte of vanilla orchids. Microscopy Research Technique, 77, 874-885. doi: 10.1002/jemt.22410

Wood, C.B., Pritchard, H.W. \& Miller, A.P. (2000). Simultaneous preservation of orchid seed and its fungal symbiont using encapsulation-dehydration is dependent on moisture content and storage temperature. CryoLett , 21, 125-36.

WWF Colombia (2008). Plan de Acción del Complejo 
Ecorregional Chocó-Darién. Cali, Colombia. ISSB: 978-958-8353-04-3.

Zettler, L.W., Corey, L.L., Richardson, L.W., Ross, A.Y. \& Moller-Jacobs, L. (2011). Protocorms of an epiphytic orchid (Epidendrum amphistomum A. Richard) recovered in situ, and subsequent identification of associated mycorrhizal fungi using molecular markers. European Journal of Environmental Sciences, 1, 108-114.

Zettler, L.W., Poulter, S.B., McDonald, K.I. \& Stewart, S.L. (2007). Conservation-driven propagation of Epidendrum nocturnum (Orchidaceae) with a mycorrhizal fungi. HortScience, 42, 135-139. 